\title{
Constructed Borrow-Pit Wetlands as Habitat for Aquatic Birds in the Peace Parkland, Canada
}

\author{
Eva C. Kuczynski and Cynthia A. Paszkowski \\ Department of Biological Sciences, University of Alberta, Edmonton, AB, Canada T6G 2E9 \\ Correspondence should be addressed to Eva C. Kuczynski, eva.kucz@gmail.com
}

Received 16 July 2012; Accepted 2 August 2012

Academic Editors: A. Chappelka, T. Muotka, D. Pimentel, and E. Serrano Ferron

Copyright ( 2012 E. C. Kuczynski and C. A. Paszkowski. This is an open access article distributed under the Creative Commons Attribution License, which permits unrestricted use, distribution, and reproduction in any medium, provided the original work is properly cited.

\begin{abstract}
The Peace Parkland, Alberta, Canada is part of a continentally important region for breeding and migrating aquatic birds. As a result of resource development and agricultural conversion, many wetlands have been lost. Road construction in the area results in the creation of borrow pits, $<3$ ha ponds created when soil is removed to form the road bed. We surveyed 200 borrow pits for aquatic birds in May through August 2007. We examined patterns of occurrence and richness, categorizing ponds based on surrounding landscape type: agriculture $(0-33.3 \%$ forest within $500 \mathrm{~m})$, mixed habitat $(33.4-66.6 \%$ forest), and forested (66.7$100 \%$ forest). Principal Component Analysis indicated that pond environments differed based on local and landscape features. Twenty-seven species of aquatic birds used borrow pits, with 13 nesting. Nonmetric Multidimensional Scaling and Indicator Species Analysis of birds observed in each month revealed assemblages characteristic of agricultural ponds, including horned grebe, lesser scaup, American coot, and mallard, and of ponds with $>33.3 \%$ forest, including bufflehead, ring-necked duck, greenwinged teal, and American wigeon. Because borrow pits were used by a variety of dabbling and diving aquatic birds in repeatable assemblages across the breeding season, we propose that these wetlands be integrated into avian conservation strategies.
\end{abstract}

\section{Introduction}

Constructed ponds are used by aquatic birds for several purposes. They can function as temporary resting and refueling stops in spring and fall for birds en route to more northerly breeding areas or southerly wintering areas. Birds may also settle and breed on them. Drought conditions negatively affect the availability of breeding habitat for aquatic birds in western Canada, and it is likely that migrating birds move northward seeking deeper, more permanent wetlands when preferred habitat is nonexistent in dry years on the prairies [1]; constructed ponds may meet their needs. Constructed wetlands may add habitat to the landscape when many natural sites have been destroyed or degraded. Since the 1950s, agricultural expansion in western Canada, and especially in Alberta, has resulted in wetland degradation and destruction, and accompanying declines in populations of breeding waterfowl [2]. At least $64 \%$ of marshes have been lost as a result of development in the settled south and central regions of Alberta [3]. Development due to oil and gas extraction in boreal Alberta is proceeding rapidly, involving large-scale habitat fragmentation, road construction [4], and tremendous wetland loss in the northern half of the province.

Habitat needs of aquatic birds vary depending on each species' vagility and foraging strategy. Dabbling ducks, such as mallard (Anas platyrhynchos), will move broods an average of $200 \mathrm{~m}$ over land to find feeding ponds [5], so it is not crucial to have good nesting and foraging resources at the same wetland. Nesting grebes and American coots (Fulica americana), in contrast, rely exclusively on within pond resources both for breeding and foraging. Diving ducks, such as lesser scaup (Aythya affinis) and bufflehead (Bucephala albeola), exhibit foraging and nesting behaviour intermediate between dabblers and grebes; these ducks use fewer wetlands during the breeding season than dabbling ducks but are not limited to one site [6]. General landscape features, such as whether a pond is located in agricultural or forested upland, may be important in breeding habitat selection. Species found in northwestern Alberta are adapted to breed in forest, parkland, or grassland, possibly as a consequence 
of nesting requirements. Dabbling ducks such as mallard, blue-winged (Anas discors), and green-winged teal (Anas carolinensis) create their nests upland of waterbodies, using grasses and forbs for nesting material, and are thus well adapted for nesting in prairie and open parkland. Bufflehead and common goldeneye (Bucephala clangula), however, require tree snags for nesting, which are more common in continuous forest. Because birds such as horned grebe (Podiceps auritus) and American coot create floating nests on the water, upland habitat type may not strongly influence these species when they select breeding ponds.

Borrow-pit constructed ponds provide a unique system for studying the ecology of aquatic birds and are a common feature on the landscape across prairie Canada. In the Peace Parkland of northwest Alberta, there are hundreds of borrow pits scattered across different landscape types, ranging from agriculture-dominated to heavily forested. A drive along the area's highways will show that borrow pits are frequently occupied by a variety of aquatic birds; however, very little is known about the structure and functioning of these communities. The ponds were constructed for a common purpose and are thus quite uniform in morphometry compared to natural wetlands. We adopted this system, and a classic community ecology approach, to better understand factors shaping the use by aquatic birds of small, constructed ponds. Specifically, we asked the following questions: (1) do repeatable assemblages of birds occur on ponds in different landscape types (ranging from forest to agriculture)? and (2) is there a seasonal shift in patterns of pond use by aquatic birds, from spring through summer, reflecting less predictable use during migration (May and August) and more focused habitat selection during breeding (June and July)?

1.1. Study System. The Peace Parkland of northwestern Alberta, Canada, is an important breeding area and flyway for thousands of aquatic birds in North America [7]. Historically, the region was a mosaic of Boreal Mixed-wood Forest and Aspen Parkland. It has been greatly modified by forestry and the energy sector, but particularly by agriculture. Construction of roads resulted in the creation of borrow pits, uniform rectangular basins excavated along highways to collect soil for road beds. Borrow pits often fill with water forming ponds and thus have incidentally compensated for the destruction of natural wetlands. Forested areas are covered by white spruce (Picea glauca), poplar (Populus species), black spruce (Picea mariana), and tamarack (Larix laricina) and are interspersed with pastures and fields of hay and row crops, such as canola.

Borrow pits are located along the sides of the highways that run throughout the Peace Parkland. They were constructed in the late 1960s and 1970s when highways were paved or twinned (T. McLaughlin, Alberta Transportation, personal communication). They are generally rectangular, with open water centers, ringed by emergent and riparian vegetation. They are on average $38 \mathrm{~m}$ from the side of the road (ranging from 8 to $126 \mathrm{~m}$ ) and range in size from 0.1 to $2.6 \mathrm{ha}$ (average area $0.6 \mathrm{ha}$ ). The distance between ponds varies; however, they are typically separated by several hundred meters. The trophic state of ponds in this study ranged from mesotrophic to hypereutrophic, based on total phosphorus (TP) [8]. TP ranged from 13 to $231 \mu \mathrm{g} / \mathrm{L}$, total nitrogen (TN) ranged from 449 to $2470 \mu \mathrm{g} / \mathrm{L}$ and chlorophyll-a ranged from 0.36 to $116.84 \mu \mathrm{g} / \mathrm{L}$; see Kuczynski [9] for further limnological characterization of borrow pits.

\section{Methods}

2.1. Surveys. Two-hundred borrow pits in northwest Alberta (from $55.43 \mathrm{~N},-116.76 \mathrm{~W}$ to $58.98 \mathrm{~N},-117.63 \mathrm{~W}$; Figure 1) were surveyed monthly, from May through August 2007 (4 surveys). Surveys were conducted between 07:00 and 17:00 h. Ponds were initially surveyed from the road, prior to approach on foot, to avoid missing birds that were inadvertently flushed. The two observers then took up different positions along the shoreline (thus decreasing the chance of missing birds) and spent an average of five minutes at each pond. At the end of a session, noise was made (i.e., hand clapping) to flush secretive birds. All nonpasserine aquatic birds observed on the water's surface or on the shoreline were recorded, as were all nonpasserine birds heard but not seen. Birds flying overhead were only recorded if they landed on or took-off from the pond. The number of adults and chicks present were recorded for each species on a pond; however, only occurrence (presence/absence) of each species is used in analyses presented here.

2.2. Landscape Characterization. We used a combination of digitized air photos and images from Google Earth (Google Earth 4.2.0205.5730) in ArcGIS Version 9.2 (ESRI, Redlands, California) to calculate the proportions of dominant landcover categories within a $500 \mathrm{~m}$ buffer area around each pond. Mensing et al. [10] found that wetland-associated birds responded to relatively small $(500 \mathrm{~m}$ and $1 \mathrm{~km})$ landscape scales. Thus we chose a $500 \mathrm{~m}$ buffer to characterize terrestrial habitat associated with each pond. Although eight land-cover categories were delineated (agriculture, forest, water, roads, homestead, industry, forestry cut-block, and other), agriculture (row crop production, hay production, and pasture) and forest were the dominant land cover types and were used to group ponds for analyses. As the proportions of agriculture and forest were highly correlated (Spearman's rho $=-0.93, P<0.0001$ ), only the proportion of forest was actually used. All ponds had some forest within their buffers, whereas many heavily forested ponds had no agriculture. Ponds were categorized into three groups based on the proportion of forest within the $500 \mathrm{~m}$ buffer: $0-33.3 \%$ forest (hereafter referred to as "agriculture", $n=91$ ponds), $33.4-66.6 \%$ forest ("mixed habitat", $n=44$ ), and $66.7-100 \%$ forest ("forest", $n=65$ ), Figure 2.

2.3. Habitat Parameters. In order to describe the habitat provided by borrow pits, we recorded a variety of parameters at each pond. Surface area and distance from the road were estimated in May with a digital rangefinder. The proportions of riparian vegetation (trees and shrubs, typically Populus or Salix spp.) and emergent vegetation (generally Typha latifolia but occasionally Carex or Juncus spp.) directly surrounding 

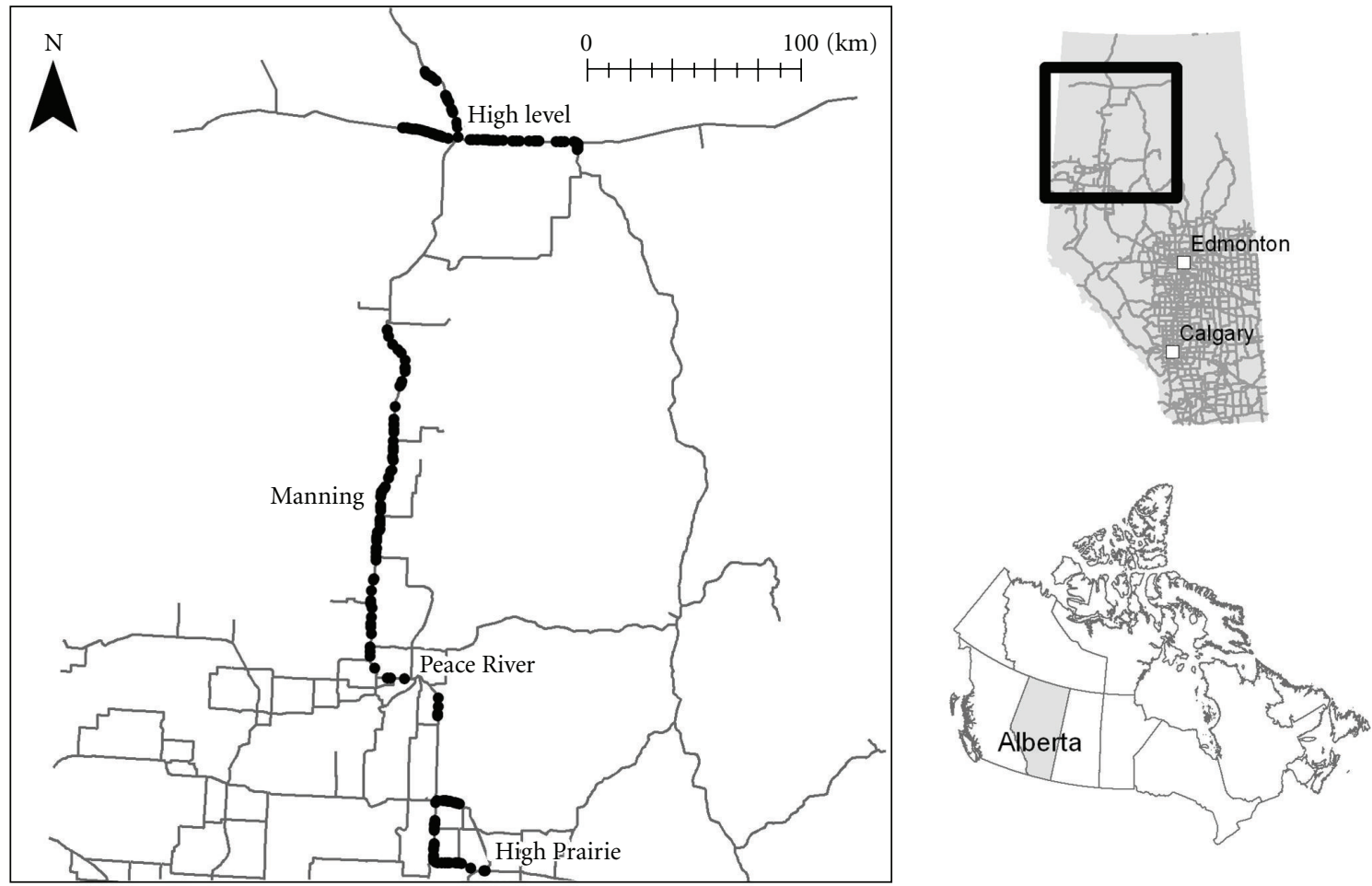

FigURE 1: Map of the 200 borrow-pit ponds (black dots) surveyed for aquatic birds in the Peace Parkland, Alberta.

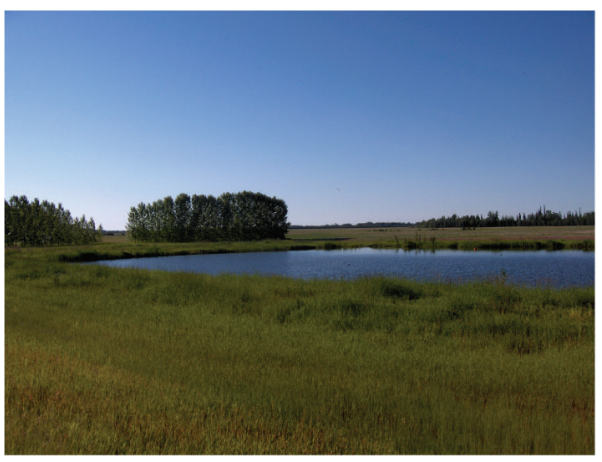

(a)

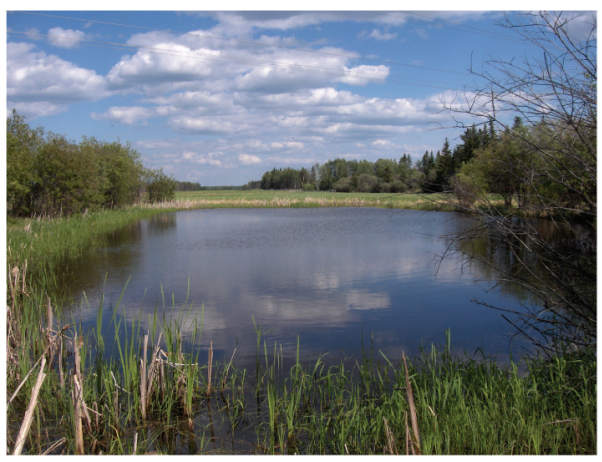

(b)

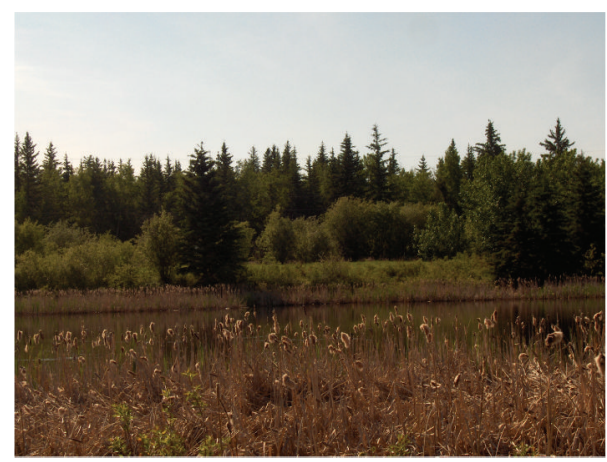

(c)

Figure 2: Examples of borrow pits in the Peace Parkland, Alberta study area: (a) agricultural pond (0-33.3\% forest within a $500 \mathrm{~m}$ pond buffer), (b) mixed habitat pond (33.4-66.6\% forest), and (c) forest pond (66.7-100\% forest). 
the perimeter of each pond, as well as the proportion of pond surface area covered by emergent vegetation (a measure of the width of this vegetative zone), were also recorded. Coverage by vegetation was visually estimated in $5 \%$ increments in August when vegetation was abundant. The Bayley and Prather [11] index of submersed aquatic vegetation (SAV) was recorded for each pond in July 2007 by ranking the proportion of the pond covered by SAV as a score, $1-5$, with 1: $0 \%, 2:<5 \%, 3: 5-25 \%, 4: 25-75 \%$, and 5: $>75 \%$. SAV can be indicative of the nature of primary production within lakes [12]. We also recorded whether beaver (Castor canadensis) activity was visible at the pond site, either within a pond (presence of a beaver and/or lodge) or immediately adjacent to the pond (marked or felled trees), as beavers can influence wetland use by aquatic birds [13]. Evidence of human structures was recorded for each pond, typically consisting of the presence of a man-made structure within a pond, such as an aerator, pump, or dock. Because wetland isolation can be an important factor determining use by aquatic birds [14], the proportion of each $500 \mathrm{~m}$ buffer that was occupied by standing or flowing water was also measured in ArcGIS, in addition to the straight-line distance from the edge of each pond to the edge of the next nearest water body.

2.4. Statistical Analysis. Data analysis was conducted with SPSS 16.0 for Windows (SPSS Inc. Chicago, IL, USA) and PC-ORD 5.0 for Windows [15]. Proportions were arcsine square-root transformed prior to analyses. A significance level of $\alpha=0.05$ was used for all analyses unless otherwise stated. When multiple comparisons were necessary, the Bonferroni correction was used to calculate an adjusted $\alpha$ (new $\alpha=0.05 /$ number of comparisons) [16].

2.4.1. Characterization of Landscape Types. We used Principal Components Analysis (PCA) as an exploratory technique to determine if ponds formed natural groupings based on the 11 parameters, described in the "Habitat parameters" section above, and assess whether our a priori designation of the three landscape types was justified. We used a correlation cross-products matrix to center and standardize all variables [17]. We conducted a Multiresponse Permutation Procedure (MRPP), with Euclidean (Pythagorean) distance measure [17], on the raw data matrix to determine if ponds classified, based on landscape type, differed in local habitat features within the $500 \mathrm{~m}$ buffer. Significance of PCA axes was determined with a randomization test within PC-ORD, where data for ponds were shuffled within columns of habitat parameters and eigenvalues were recalculated and compared with original values [17].

\subsubsection{Examining Patterns of Occurrence and Species Richness.} To test for differences in pond occupancy (occurrence of at least one species of aquatic bird) among the four months within the 2007 field season, we conducted a Cochran's q test (with McNemar tests for pairwise comparisons). To test for differences in pond occupancy within months, among the three landscape groups (agriculture, mixed habitat, forest), we performed Kruskal-Wallis tests. To assess whether species richness was consistent across the four study months, or whether use by aquatic birds was specific to particular times during the study period, we compared species richness among months using a Friedman's test; pairwise comparisons were then made with Wilcoxon signed-rank tests.

\subsubsection{Visualizing Assemblages of Aquatic Birds. We used} Nonmetric Multidimensional Scaling (NMS) to visualize bird assemblages present on borrow pits in May, June, July, and August. We included all species that were present on $\geq 5 \%$ of ponds (i.e., minimum of 10 ponds); therefore, there were some differences in species included in analyses for May (12 species), June (10 species), July (7 species), and August (8 species). It was necessary to include a dummy variable "ALL" (constant value of 1 for all ponds) in order to include all ponds in the ordination (including ponds with no birds), and to be able to compare ordinations among months. We used "slow and thorough" autopilot mode in PC-ORD with Sorensen (Bray-Curtis) distance measure, recommended for community data, and a random starting configuration [17]. An MRPP was conducted on presence/absence raw data matrices for each month, using Sorensen distance, to test for differences in bird assemblages among the three landscape types.

2.4.4. Indicator Species of Landscape Types. We performed indicator species analyses [18] on data from each month, grouped by landscape type. Indicator species analysis identifies species that characterize specific landscape types. A "perfect" indicator species is always (and only) found on one site type $[17,18]$. For this analysis, we grouped ponds together if they were surrounded by more than $33.3 \%$ forest (as the "mixed habitat" and "forest" groups did not differ based on MRPP tests), resulting in two groups: an "agriculture" group and a "mixed + forest" group.

\section{Results}

3.1. Relationships among Ponds and Habitat Parameters. PCA axes 1 and 2 were significant $(P=0.001)$ according to a randomization test, axes 1 and 2 explaining $24.8 \%$ and $14.7 \%$ of total variance, respectively (Figure 3). An MRPP based on habitat parameters for agricultural, mixed habitat, and forested ponds indicated that groups differed significantly ( $A=0.12, P<0.001$ ). Pairwise comparisons (with Bonferroni adjusted $\alpha=0.017$ ) revealed statistically significant differences among each of the three landscape types $(P<$ 0.001 for agricultural versus mixed habitat and agricultural versus forested, $P=0.012$ for mixed habitat versus forested). Most agricultural ponds were farther south and smaller, had less emergent, riparian, and submersed aquatic vegetation, and were less likely to have beaver activity than forested ponds (Table 3). There was also less water on the landscape surrounding ponds in agriculture-dominated areas, both in terms of amount within $500 \mathrm{~m}$ of a pond and the distance to the nearest water body (although this parameter had a proportionately smaller effect). Mixed habitat ponds were 


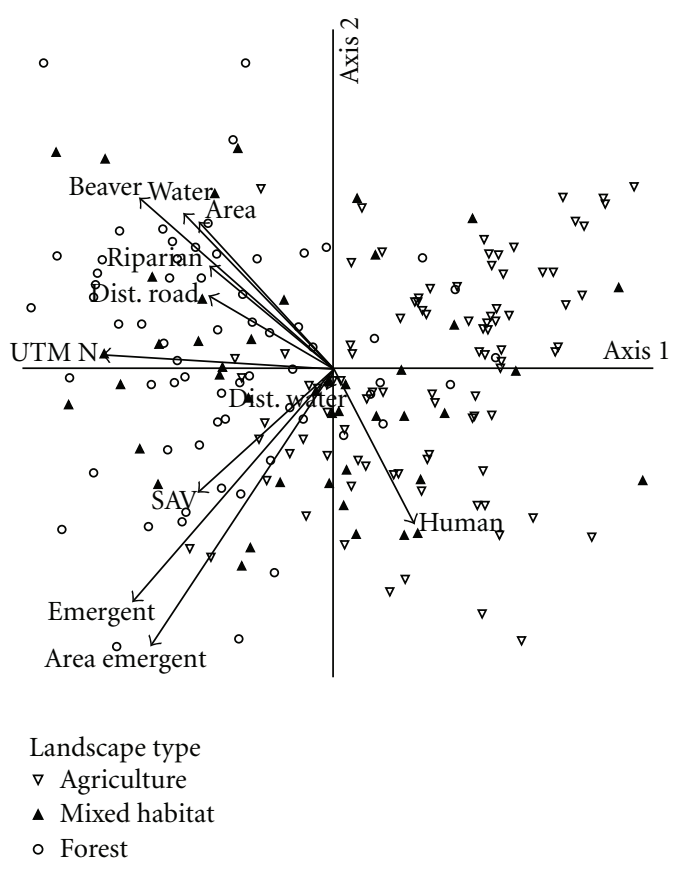

Figure 3: Principal Components Analysis plot of values for axes 1 and 2 based on habitat parameters for 200 borrow-pit ponds coded as agriculture $(0-33.3 \%$ forest, $n=91)$, mixed habitat $(33.4-66.6 \%$ forest, $n=44)$, or forest $(66.7-100 \%$ forest, $n=65)$ landscape types, as determined by land-cover within a $500 \mathrm{~m}$ pond buffer area. Vectors indicate the strength and direction of habitat parameters (see Table 3 for abbreviations and description of parameters).

intermediate in habitat features between agricultural and forested ponds.

3.2. Occurrence of Aquatic Birds on Borrow Pits. Occupancy differed among survey months (Table 1); May occupancy was highest with $90 \%$ of ponds supporting at least one bird $(P \leq 0.001)$, and there was no difference among other months $(78-80 \%, P \geq 0.66)$. There was no difference in pond occupancy among the three landscape types during any of the four surveys (May: $\chi_{2}^{2}=1.93, P=0.38$; June: $\chi_{2}^{2}=3.00, P=0.22$; July: $\chi_{2}^{2}=1.09, P=0.58$; August: $\left.\chi_{2}^{2}=0.01, P=1.00\right)$.

Species richness varied among survey months $\left(\chi_{3}^{2}=\right.$ $78.30, P<0.001$ ). May richness (range: $0-9 ; 22$ species total) was highest of all months, and August richness (range: 0-7; 20 species total) was significantly higher than July (range: 0 5; 16 species total; $P \leq 0.002$ ). June richness ranged between 0 to 6 (22 species total).

The most commonly observed species were horned grebe, bufflehead, ring-necked duck (Aythya collaris), and lesser scaup, although a total of 27 species were observed using borrow pits throughout the summer (Table 2). Of these, 13 were common (observed on each survey), 10 were occasional (observed on two or three surveys), and four were rare (observed on only one survey). Thirteen species bred on borrow pits over the course of the summer (chicks were observed).
3.3. Assemblages of Aquatic Birds. MRPP tests revealed that bird assemblages on ponds in different landscape types differed significantly for all four months; however, pairwise comparisons indicated that although assemblages on agricultural ponds were consistently distinct from assemblages on both mixed habitat and forested ponds, assemblages on mixed habitat and forested ponds did not differ, following the Bonferroni adjustment for $\alpha$ of 0.017 (Table 4, Figure 4).

3.4. Aquatic Birds as Indicators of Landscape Types. According to indicator species analysis, based on Monte Carlo significance tests, horned grebe was the only species that was consistently an indicator of agricultural ponds in each of the four months (Table 5). Lesser scaup was also an indicator of agricultural ponds from May through July. American coot was an indicator of agricultural ponds, but only in May, and mallard was an indicator of agricultural ponds in June.

Bufflehead was an indicator of forested ponds for all four months. Ring-necked duck was also an indicator of the same mixed + forest ponds in three months (May, June, and August), and green-winged teal was an indicator in two months (May and June). American wigeon (Anas americana) was an indicator of mixed + forest ponds only in May (Table 5).

\section{Discussion}

Wetlands in Alberta provide continentally important nesting habitat for many populations of aquatic birds [7]. Like most of prairie Canada, Alberta has lost hundreds of natural wetlands, either completely or partially through impairment of wetland services $[2,19]$, resulting in less available habitat for aquatic birds. Borrow pits, constructed throughout the province, have incidentally created avian habitat for aquatic species. We explored patterns associated with occurrence of aquatic birds on borrow pits in the Peace Parkland. The nature of surrounding terrestrial habitat was an obvious feature that distinguished large blocks of ponds; therefore, we examined landscape in more detail. We were also interested if the use of ponds by aquatic birds in the Peace Parkland changed seasonally, from May through August, reflecting use of borrow pits during migration versus as sites for nesting and chick rearing.

A variety of dabbling and diving birds used borrow pits for either nesting, foraging, or as a stopover area during migration. Borrow pits in the Peace Parkland attracted similar species to natural wetlands found elsewhere in the Prairie and Parkland Region [20-22]. Both species richness and composition recorded on borrow pits were similar to the assemblages of two to eight species found on nine small (minimum $2.7 \mathrm{ha}$ ) shallow lakes in the boreal transition zone of north central Alberta [23]. However, species richness tended to be lower on borrow pits (max. richness $=9$ ) than on wetlands in the Aspen Parkland (max. richness $=23$ species on 25 waterbodies in the Beaver Hills, Alberta) [22]. Minimum richness on natural parkland wetlands and boreal transition lakes was never observed to be zero; however, a complete lack of birds was recorded on $10-22 \%$ of the 200 borrow pits during monthly surveys in the Peace Parkland. 


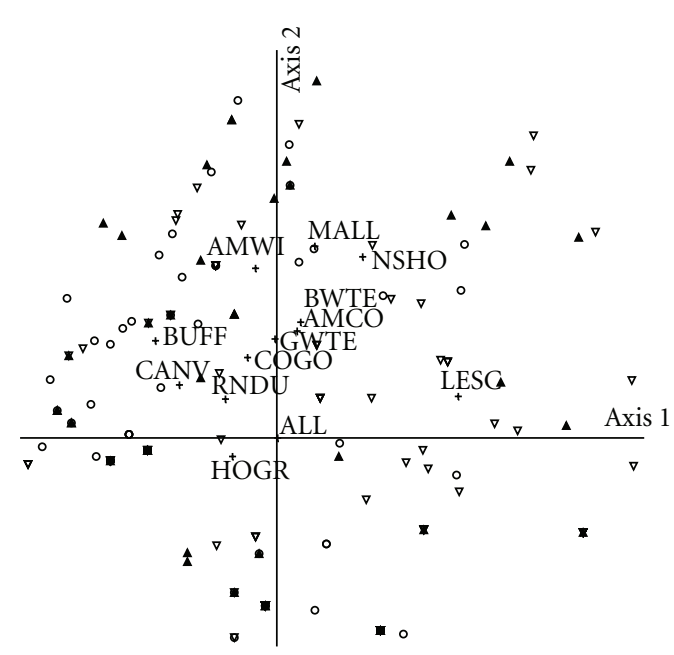

(a)

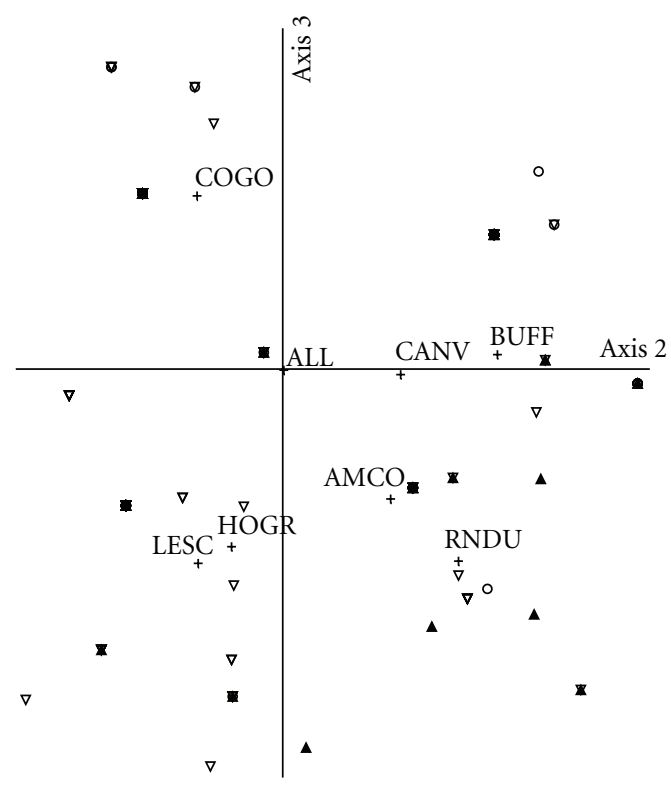

Landscape type

$\nabla$ Agriculture

- Mixed habitat

- Forest

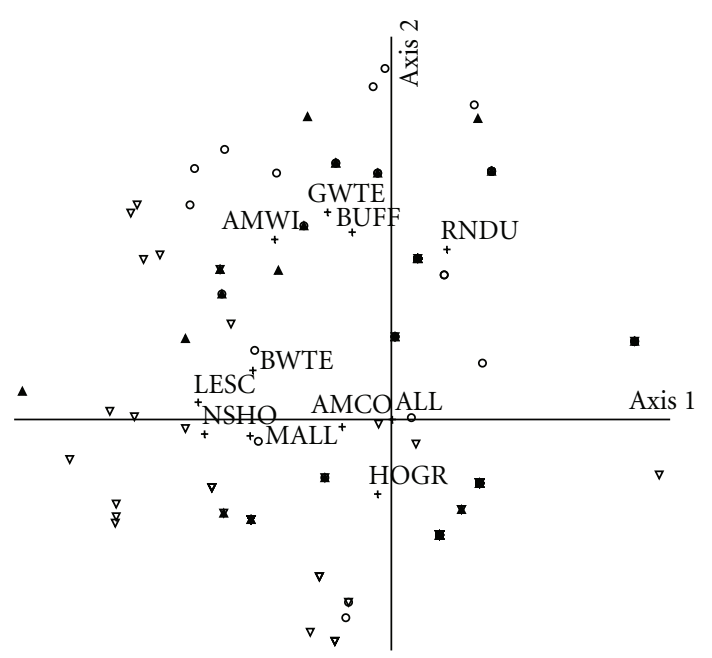

(b)

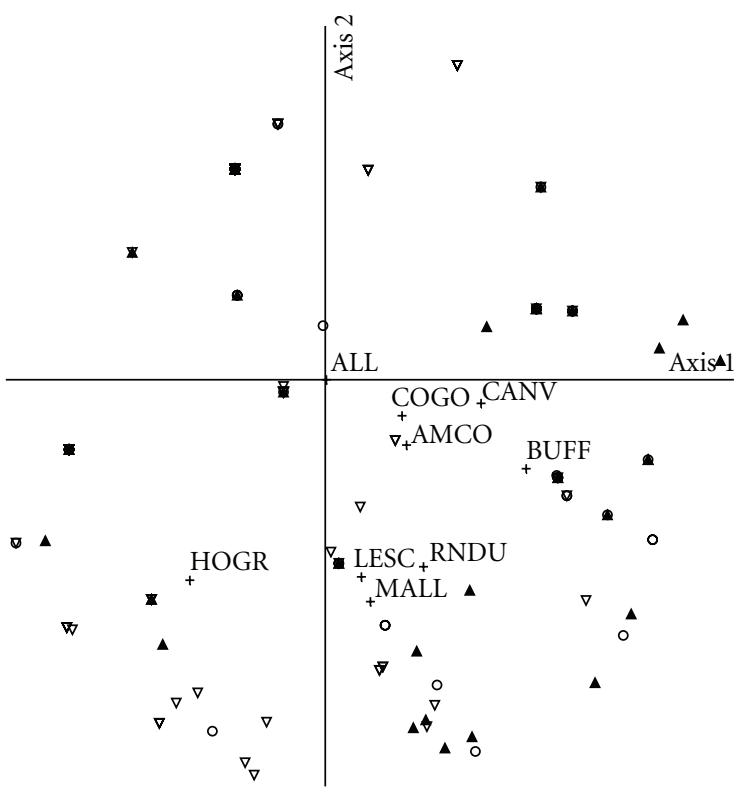

(c)

(d)

FIgURE 4: Nonmetric Multidimensional Scaling ordination plots of bird assemblages in (a) May presence/absence of 12 species, (b) June presence/absence 10 species, (c) July presence/absence of 7 species, and (d) August presence/absence of 8 species of aquatic birds across 200 ponds surveyed in 2007 in the Peace Parkland, Alberta. Landscape types are coded by agricultural ponds $(0-33.3 \%$ forest within a 500 m pond buffer, $n=91)$, mixed habitat ponds (33.4-66.6\% forest, $n=44)$, forest ponds $(66.7-100 \%$ forest, $n=65)$. "ALL" is a dummy variable, included in order to keep all ponds in analyses (see text). See Table 2 for species codes.

With the assistance of biologists from Ducks Unlimited Canada and Alberta Conservation Association, we attempted to locate natural roadside ponds that were analogous to the borrow pits. We had very limited success: 8 natural roadside wetlands in the Peace Parkland (0.13-1.79 ha) supported up to 8 species of aquatic birds in 2007. An additional 10 natural wetlands were surveyed in $2008(0.26-5.31 \mathrm{ha})$ and supported up to 11 species [9].
Although the makeup of the landscape surrounding ponds was not uniform and formed a gradient based on the extent of forest cover, we arbitrarily divided ponds into three groups to examine patterns of pond use across a range of spatial scales. PCA on habitat data revealed that the local habitat offered by agricultural, mixed habitat and forested pond types was distinct. Agricultural ponds were mostly at one end of this gradient and forested ponds at the other, 
TABle 1: Percent of 200 borrow-pit ponds occupied by at least one species of aquatic bird during surveys in May, June, July, and August 2007 in agricultural $(0-33.3 \%$ forest within a $500 \mathrm{~m}$ pond buffer, $n=91)$, mixed habitat $(33.4-66.6 \%$ forest, $n=44)$, and forested $(66.7-100 \%$ forest, $n=65$ ) landscapes in the Peace Parkland, Alberta.

\begin{tabular}{lcccc}
\hline Landscape type & & & Survey month & \\
& May & June & July & 76.9 \\
Agriculture & 87.9 & 72.5 & 84.1 & 80.2 \\
Mixed habitat & 95.5 & 84.1 & 81.5 & 79.6 \\
Forest & 89.2 & 81.5 & 80.0 & 80.0 \\
All ponds & 90.0 & 78.0 & & 80.0 \\
\hline
\end{tabular}

TABLE 2: Summary of aquatic birds observed on 200 borrow-pit ponds in northwestern Alberta in May-August 2007. Status codes are C = common (observed on all surveys), $\mathrm{O}=$ occasional (observed on more than one survey), $\mathrm{R}=$ rare (observed once), $\mathrm{B}=\mathrm{breeding}$ (chicks observed). The number of occupied ponds (out of 200) is presented for May, June, July, and August.

\begin{tabular}{|c|c|c|c|c|c|c|c|}
\hline \multirow{2}{*}{ Common name } & \multirow{2}{*}{ Code } & \multirow{2}{*}{ Latin name } & \multirow{2}{*}{ Status } & \multicolumn{4}{|c|}{ Species occurrences } \\
\hline & & & & May & June & July & August \\
\hline Canada goose & CAGO & Branta canadensis & C, B & 4 & 2 & 7 & 2 \\
\hline Gadwall & GADW & Anas strepera & $\mathrm{O}$ & 0 & 2 & 1 & 1 \\
\hline American wigeon & AMWI & Anas americana & $\mathrm{C}, \mathrm{B}$ & 30 & 18 & 6 & 4 \\
\hline Mallard & MALL & Anas platyrhynchos & C, B & 46 & 12 & 9 & 24 \\
\hline Blue-winged teal & BWTE & Anas discors & $\mathrm{O}$ & 12 & 12 & 3 & 0 \\
\hline Northern shoveler & NSHO & Anas clypeata & C, B & 25 & 10 & 3 & 5 \\
\hline Northern pintail & NOPI & Anas acuta & $\mathrm{O}$ & 1 & 0 & 0 & 3 \\
\hline Green-winged teal & GWTE & Anas carolinensis & $\mathrm{O}, \mathrm{B}$ & 23 & 9 & 0 & 4 \\
\hline Canvasback & CANV & Aythya valisineria & C, B & 15 & 7 & 13 & 17 \\
\hline Redhead & REDH & Aythya americana & $\mathrm{C}$ & 4 & 3 & 1 & 1 \\
\hline Ring-necked duck & RNDU & Aythya collaris & C, B & 39 & 23 & 17 & 31 \\
\hline Lesser scaup & LESC & Aythya affinis & C, B & 33 & 39 & 18 & 43 \\
\hline Surf scoter & SUSC & Melanitta perspicillata & $\mathrm{R}$ & 2 & 0 & 0 & 0 \\
\hline Bufflehead & BUFF & Bucephala albeola & C, B & 86 & 61 & 78 & 68 \\
\hline Common goldeneye & COGO & Bucephala clangula & C, B & 18 & 6 & 10 & 22 \\
\hline Barrow’s goldeneye & BAGO & Bucephala islandica & $\mathrm{O}$ & 4 & 2 & 0 & 0 \\
\hline Hooded merganser & HOME & Lophodytes cucullatus & $\mathrm{R}$ & 0 & 0 & 0 & 2 \\
\hline Ruddy duck & RUDU & Oxyura jamaicensis & C, B & 5 & 4 & 1 & 5 \\
\hline Horned grebe & HOGR & Podiceps auritus & C, B & 100 & 84 & 84 & 61 \\
\hline American coot & AMCO & Fulica americana & C, B & 13 & 10 & 22 & 21 \\
\hline Sora & SORA & Porzana carolina & $\mathrm{O}$ & 0 & 3 & 1 & 0 \\
\hline Lesser yellowlegs & LEYE & Tringa flavipes & $\mathrm{O}$ & 1 & 0 & 0 & 1 \\
\hline Solitary sandpiper & SOSA & Tringa solitaria & $\mathrm{O}$ & 1 & 2 & 0 & 2 \\
\hline Spotted sandpiper & SPSA & Actitis macularia & $\mathrm{O}$ & 0 & 0 & 0 & 8 \\
\hline Common snipe & COSN & Gallinago gallinago & $\mathrm{O}$ & 5 & 1 & 0 & 2 \\
\hline Black tern & BLTE & Chlidonias niger & $\mathrm{R}$ & 0 & 0 & 0 & 1 \\
\hline Common tern & COTE & Sterna hirundo & $\mathrm{R}$ & 2 & 0 & 0 & 0 \\
\hline
\end{tabular}

whereas mixed habitat ponds were intermediate (Figure 3). Procedures during excavation of borrow pits may explain some of the differences in habitat across the three groups of ponds. Ponds were larger in northern forested areas and smaller in southern agricultural areas. Likewise, agricultural ponds were on average one meter deeper than forested ponds $(\bar{x}=3.3 \mathrm{~m}$ for agricultural ponds and $2.2 \mathrm{~m}$ for forested ponds, based on a subset of 29 of these ponds) [9]. Shallower forested ponds had more emergent vegetation surrounding them, and SAV within them, than deeper agricultural ponds. Likewise, the disturbance incurred by agricultural activities frequently removed riparian vegetation from the edges of agricultural ponds. Clearing along shorelines was less pronounced in ponds surrounded by mixed habitat, and virtually nonexistent in heavily forested areas. Given the features characteristic of agricultural ponds (smaller and deeper, with less vegetation), one might think that they would be unattractive to aquatic birds; however, there was 


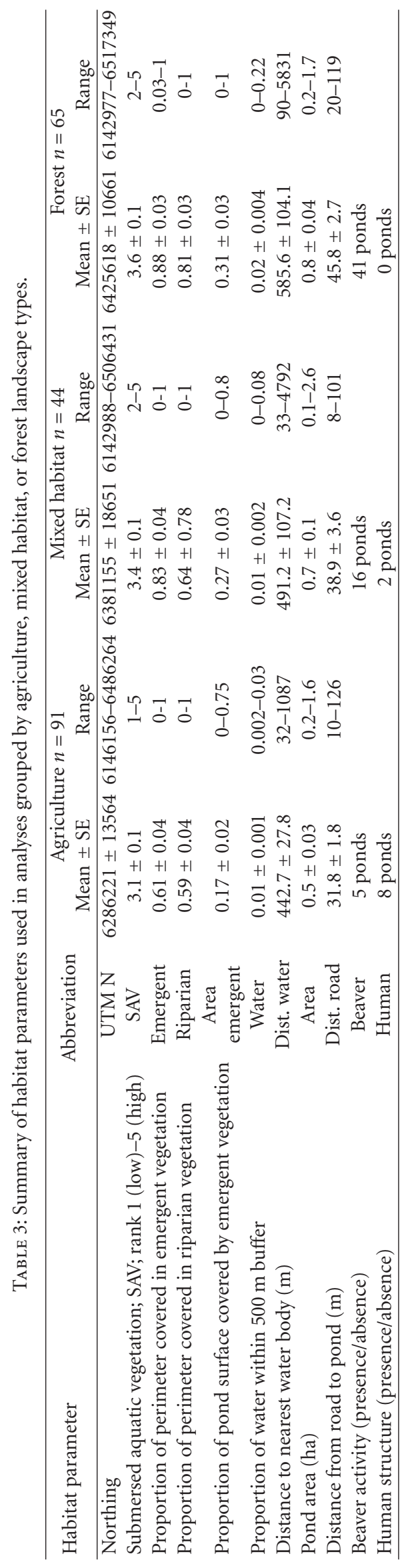




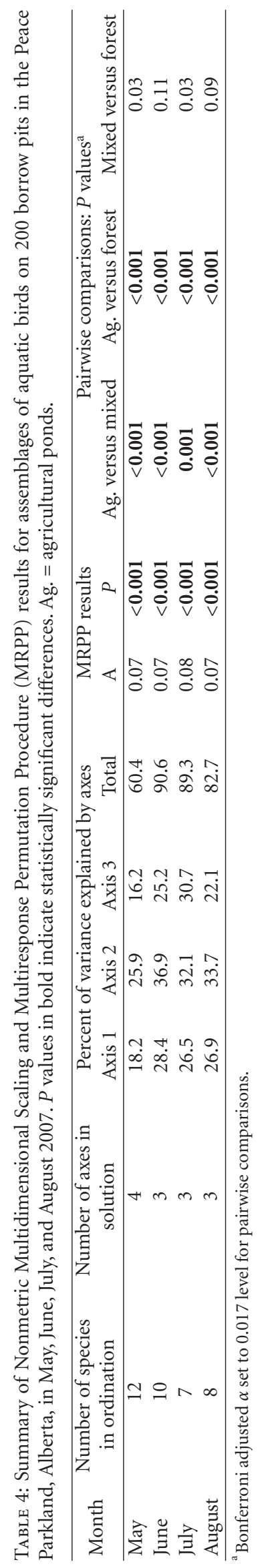




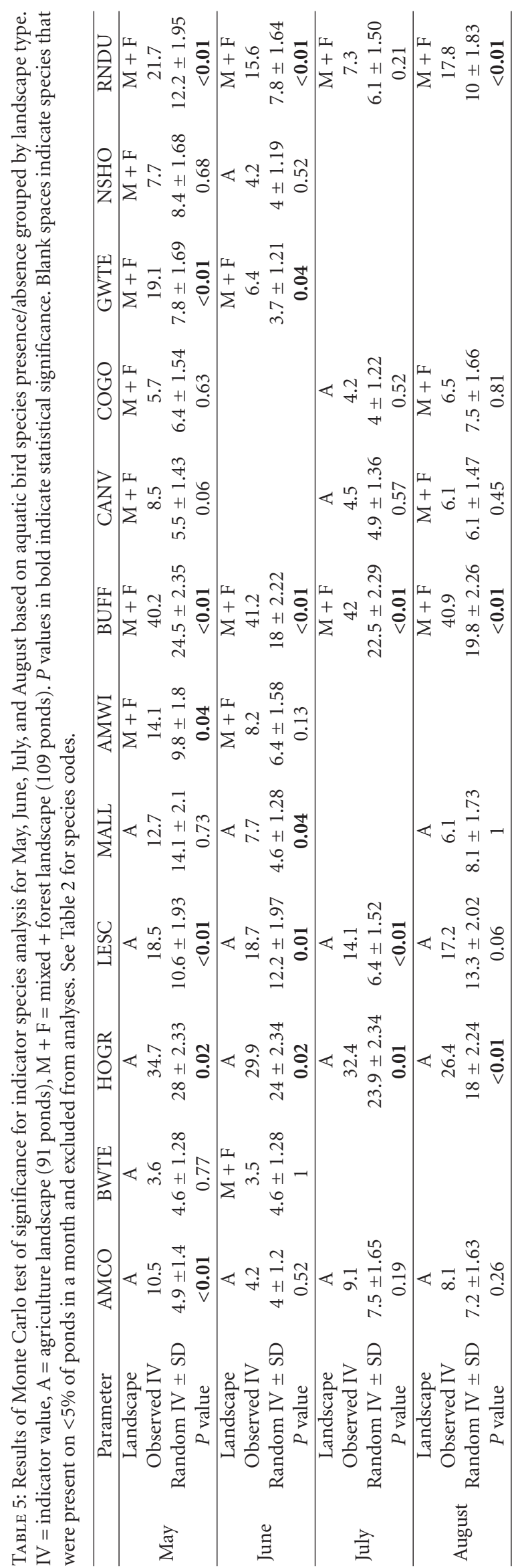


no difference in species richness among the three landscape types, and there were species that consistently occurred on ponds in agricultural areas.

Although ponds occurring in mixed habitat did not support a distinct assemblage of birds, indicator species analysis identified assemblages of birds characteristic of both agricultural ponds and ponds surrounded by at least 33\% forest (mixed + forest). Horned grebe, lesser scaup, American coot, and mallard were characteristic of agricultural ponds, whereas bufflehead, ring-necked duck, green-winged teal, and American wigeon were characteristic of mixed + forest ponds. Dwyer [24] surveyed potholes in agricultural and partially $(\sim 60 \%)$ forested landscapes in the aspen parkland of southern Manitoba and noted greater use of agricultural potholes by divers such as lesser scaup, American coot, redhead (Aythya americana), canvasback (Aythya valisineria), and horned grebe, whereas dabblers, including mallard and blue-winged teal, preferred forested potholes. Although some species were common indicators of land cover types between our study and Dwyer [24], we did not find the trend extended to entire foraging guilds. In streamside wetlands in Minnesota, Mensing et al. [10] found that blue-winged and green-winged teal were unique to agricultural sites $(<45 \%$ forest within $500 \mathrm{~m}$ ) and mallard preferred, but were not restricted to, agricultural sites (no aquatic birds were indicators of forested sites). We found no species that switched between being an indicator of different pond types between months; however, some species were only indicators in one or two months, likely indicative of decreased frequencies of occurrence of some species on ponds of a "preferred" landscape type over the course of the summer. For example, green-winged teal was a strong indicator (of mixed + forest ponds) in May $(P<0.01$ and occurring on 22 ponds), somewhat weaker in June ( $P=0.04$ and on eight ponds), and was no longer an indicator by July and August (on zero to three ponds). Decreased frequency of occurrence likely also explains the apparent drop off in the total number of significant indicators throughout the summer. On the contrary, horned grebe became stronger indicators over the duration of the summer, despite a decrease in frequency of occurrence. Horned grebe was a stronger indicator of agricultural ponds in July and August $(P<0.01)$ than May and June $(P=0.02)$, suggesting that grebes may have been still moving among ponds early in the summer and having more predictable habitat selection preferences later in the summer (Table 5). Not only are horned grebes abundant, and indicators of agricultural ponds in the Peace Parkland, but they were also found to select borrow pits based on specific local and landscape characteristics for nesting [25].

NMS revealed that assemblages of birds on agricultural ponds differed from those on both mixed habitat and forested ponds. However, although mixed habitat and forested pond types were moderately distinct based on habitat features alone (Figure 3), they did not differ from each other in their bird assemblages. It is possible that birds distinguish between ponds that are open (exposed) or relatively closed, and the degree to which ponds are surrounded by trees beyond 33\% coverage does not matter. Alternatively, it is not the amount of forest that is important, but the composition of the forested patches (e.g., the proportion of deciduous versus coniferous trees), which was not a habitat metric that we quantified.

Ponds in different landscapes have different features that either attract or repel different species. Although agricultural ponds may be warmer and thus potentially more productive early in the open water season (forested ponds may thaw more slowly due to sheltering effect of trees), they may also be more exposed to inclement weather in the spring. Ponds surrounded by more trees may offer some protection from the elements and may be more similar to natural parkland wetlands that provide habitat for species in this study. Forest surrounding ponds may be unfavorable for some divers, like the horned grebe, that require a running take off from the waters' surface [24]. However, forested ponds may be attractive to cavity nesting birds such as bufflehead and goldeneye. In our study, only bufflehead was an indicator of forested ponds; common goldeneye occurred infrequently on borrow pits, and their overall low abundance suggests that the species rarely used study ponds for nesting or broodrearing. Pöysä and Virtanen [26] found that brood-rearing lakes for common goldeneye were smaller than nesting lakes $(\bar{x}=5.6$ ha versus $\bar{x}=20.2 \mathrm{ha})$. However, these Finnish lakes were almost ten times larger than borrow pits $(\bar{x}=0.6 \mathrm{ha})$, suggesting that borrow pits may be too small to support common goldeneye broods.

Ponds in the forested landscape had more water surrounding them than did ponds in agricultural landscapes; however, the distance to the nearest water body appeared to have less influence on the characterization of ponds across landscape types than the other habitat parameters (Figure 3 ). We suspect distance to water was very similar for all ponds as this parameter included distance to other borrow pits; the closest water body to a pond was likely the next closest borrow pit. Although amount of water on the landscape also included water from both natural and constructed sources, there appeared to be more natural wetlands in forested areas. Wetland density and the configuration of wetlands on the landscape are important factors for many species of aquatic birds (e.g., $[27,28]$ ). Rather than forest being the primary driving factor that determines use by aquatic birds, indicators of forested ponds may be species that use multiple wetlands during the breeding season. Green-winged teal and American wigeon, indicators of forested ponds, are dabblers, and thus capable of longer distance travel over land, however, so is the mallard, an indicator of agricultural ponds. In contrast, Riffell et al. [29] found that wetlandassociated birds (passerines and aquatic birds such as wood duck [Aix sponsa] and great blue heron [Ardea herodias]) in southern Michigan were better predicted by forest characteristics, such as structure and heterogeneity, than wetland characteristics.

Some results of our study contrast with findings from studies in other regions. Although on wetlands near Yellowknife, NWT, lesser scaup appeared to avoid borrow pits for brood rearing [30], it was one of the more abundant breeding species on ponds in our study. Borrow pits in the Peace Parkland tend to be larger and deeper than borrow pits in the Yellowknife study area (median size $<0.1 \mathrm{ha}$, depth: 
unmeasured but reported as "semi-permanent") [31], which could account for relatively low use by divers in NWT.

Both occurrence and richness were highest in May, most likely indicative of birds using ponds temporarily as they migrated further north. A similar influx of migrants was observed in August, as species richness was higher than in July. In early August, birds were beginning their southward migration, and birds of the year were leaving breeding ponds. When looking in detail at May versus June patterns of pond use, it appears that aquatic birds might be less selective in May than in June. By June, birds had either departed for other areas or settled to breed, and thus displayed narrower patterns of habitat use. This is illustrated by the greater proportion of variance in the composition of bird assemblages explained by the ordination in June (90.6\%) than in May (60.4\%). Variance explained remained high in July $(89.3 \%)$ and then decreased slightly in August $(82.7 \%)$, suggesting that patterns of assemblage composition were beginning to degrade at the end of the summer. In contrast, patterns for indicator species were very consistent for most species across months, such as horned grebe and bufflehead that remained consistent indicators for all four months.

\section{Conclusion}

Borrow-pit wetlands in northwestern Alberta represent a source of permanent water and are used by a variety of dabbling and diving aquatic birds, both during migration and the breeding season. In general, we found predictable assemblages of aquatic birds on borrow pits throughout the summer within agricultural and forested landscapes. Species richness was substantial (27 species), but lower than on small natural wetlands in parkland in central Alberta [22]. Based on our findings, we propose that the hundreds of existing borrow pits in the Peace Parkland, and elsewhere in western Canada, offer attractive avian habitat and should be integrated into regional bird conservation plans alongside remaining natural wetlands.

\section{Acknowledgments}

The authors would like to thank Alberta North American Waterfowl Plan, Alberta Conservation Association, Alberta Sport, Recreation, Parks and Wildlife Foundation, Canadian Circumpolar Institute (C/BAR), the Northern Scientific Training Program, the Natural Sciences and Engineering Research Council of Canada, and the University of Alberta for financial support of this project. Thanks are due to Bev Gingras and Gerry Beyersbergen from the Canadian Wildlife Service for use of their initial 2003 survey data for pond coordinates, to Leah McGraw for assistance in the field, and to Kelli Sparks for assistance with GIS analysis.

\section{References}

[1] J. E. Austin, "Responses of dabbling ducks to wetland conditions in the Prairie Pothole region," Waterbirds, vol. 25, no. 4, pp. 465-473, 2002.
[2] R. W. Bethke and T. D. Nudds, "Effects of climate change and land use on duck abundance in Canadian prairie-parklands," Ecological Applications, vol. 5, no. 3, pp. 588-600, 1995.

[3] Ducks Unlimited Canada, "Wetlands Alberta—wetland loss," 2011, http://wetlandsalberta.ca/wetland-loss/.

[4] R. Schneider and S. Dyer, "Death by a thousand cuts: impacts of in situ oil sands development on Alberta's boreal forest," The Pembina Institute and The Canadian Parks and Wilderness Society, 2006, http://www.pembina.org/pub/1262.

[5] E. H. Dzus and R. G. Clark, "Overland travel, food abundance, and wetland use by Mallards: relationships with offspring survival," Wilson Bulletin, vol. 109, no. 3, pp. 504-515, 1997.

[6] J. Elmberg, P. Nummi, H. Poysa, and K. Sjoberg, "Relationships between species number, lake size and resource diversity in assemblages of breeding waterfowl," Journal of Biogeography, vol. 21, no. 1, pp. 75-84, 1994.

[7] G. W. Beyersbergen, N. D. Niemuth, and M. R. Norton, Northern Prairie and Parkland Waterbird Conservation Plan. A Plan Associated with the Waterbird Conservation for the Americas Initiative, Prairie Pothole Joint Venture, Denver, Colo, USA, 2004.

[8] R. E. Carlson, "A trophic state index for lakes," Limnology and Oceanography, vol. 22, no. 2, pp. 361-369, 1977.

[9] E. C. Kuczynski, Habitat selection and food-web relations of horned grebes (Podiceps auritus) and other aquatic birds on constructed wetlands in the Peace Parkland, Alberta, Canada [M.S. thesis], University of Alberta, Alberta, Canada, 2009.

[10] D. M. Mensing, S. M. Galatowitsch, and J. R. Tester, "Anthropogenic effects on the biodiversity of riparian wetlands of a northern temperate landscape," Journal of Environmental Management, vol. 53, no. 4, pp. 349-377, 1998.

[11] S. E. Bayley and C. M. Prather, "Do wetland lakes exhibit alternative stable states? Submersed aquatic vegetation and chlorophyll in western boreal shallow lakes," Limnology and Oceanography, vol. 48, no. 6, pp. 2335-2345, 2003.

[12] M. Scheffer, S. H. Hosper, M. L. Meijer, B. Moss, and E. Jeppesen, "Alternative equilibria in shallow lakes," Trends in Ecology and Evolution, vol. 8, no. 8, pp. 275-279, 1993.

[13] F. Rosell, O. Bozsér, P. Collen, and H. Parker, "Ecological impact of beavers castor fiber and castor canadensis and their ability to modify ecosystems," Mammal Review, vol. 35, no. 34, pp. 248-276, 2005.

[14] M. Brown and J. J. Dinsmore, "Implications of marsh size and isolation for marsh bird management," Journal of Wildlife Management, vol. 50, no. 3, pp. 392-397, 1986.

[15] B. McCune and M. J. Mefford, Multivariate Analysis of Ecological Data, Version 5.0. MjM Software, Gleneden Beach, Ore, USA, 1999.

[16] N. J. Gotelli and A. M. Ellison, A Primer of Ecological Statistics, Sinauer Associates, Sunderland, Mass, USA, 2004.

[17] B. McCune and J. B. Grace, Analysis of Ecological Communities, MjM Software Design, Gleneden Beach, Ore, USA, 2002.

[18] M. Dufrêne and P. Legendre, "Species assemblages and indicator species: the need for a flexible asymmetrical approach," Ecological Monographs, vol. 67, no. 3, pp. 345-366, 1997.

[19] B. A. Bartzen, K. W. Dufour, R. G. Clark, and F. Dale Caswell, "525-538 Trends in agricultural impact and recovery of wetlands in prairie Canada," Ecological Applications, vol. 20, no. 2, pp. 525-538, 2010.

[20] R. E. Stewart, "Breeding waterfowl populations in the prairie pothole region of North Dakota," Condor, vol. 76, pp. 70-79, 1974. 
[21] R. Corrigan, Effectiveness of nest boxes in influencing population trends for Common goldeneye (Bucephala clangula) and Bufflehead (Bucephala albeola) in the Buffalo Lake Moraine [M.S. thesis], University of Alberta, Alberta, Canada, 2007.

[22] C. E. McParland and C. A. Paszkowski, "Waterbird assemblages in the Aspen Parkland of western Canada: the influence of fishes, invertebrates, and the environment on species composition," Ornithological Science, vol. 6, no. 2, pp. 53-65, 2007.

[23] C. A. Paszkowski and W. M. Tonn, "Effects of lake size, environment, and fish assemblage on species richness of aquatic birds," Verhandlungen Der Internationalen Vereinigung Limnologie, vol. 27, pp. 178-182, 2000.

[24] T. J. Dwyer, "Waterfowl breeding habitat in agricultural and nonagricultural land in Manitoba," The Journal of Wildlife Management, vol. 34, pp. 130-136, 1970.

[25] E. C. Kuczynski, C. A. Paszkowski, and B. A. Gingras, "Horned grebe habitat use of constructed wetlands in Alberta, Canada," The Journal of Wildlife Management. In press.

[26] H. Pöysä and J. Virtanen, "Habitat selection and survival of Common Goldeneye (Bucephala clangula) broods-preliminary results," Hydrobiologia, vol. 279-280, no. 1, pp. 289-296, 1994.

[27] S. M. Haig, D. W. Mehlman, and L. W. Oring, "Avian movements and wetland connectivity in landscape conservation," Conservation Biology, vol. 12, no. 4, pp. 749-758, 1998.

[28] N. D. Niemuth and J. W. Solberg, "Response of waterbirds to number of wetlands in the Prairie Pothole Region of North Dakota, USA," Waterbirds, vol. 26, no. 2, pp. 233-238, 2003.

[29] S. Riffell, T. Burton, and M. Murphy, "Birds in depressional forested wetlands: area and habitat requirements and model uncertainty," Wetlands, vol. 26, no. 1, pp. 107-118, 2006.

[30] P. L. F. Fast, R. G. Clark, R. W. Brook, and J. E. Hines, "Patterns of wetland use by brood-rearing Lesser Scaup in northern boreal forest of Canada," Waterbirds, vol. 27, no. 2, pp. 177182, 2004.

[31] M. A. Fournier and J. E. Hines, "Breeding ecology of the horned grebe (Podiceps auritus) in subarctic wetlands," Canadian Wildlife Service, Occasional Paper 99, 1999. 

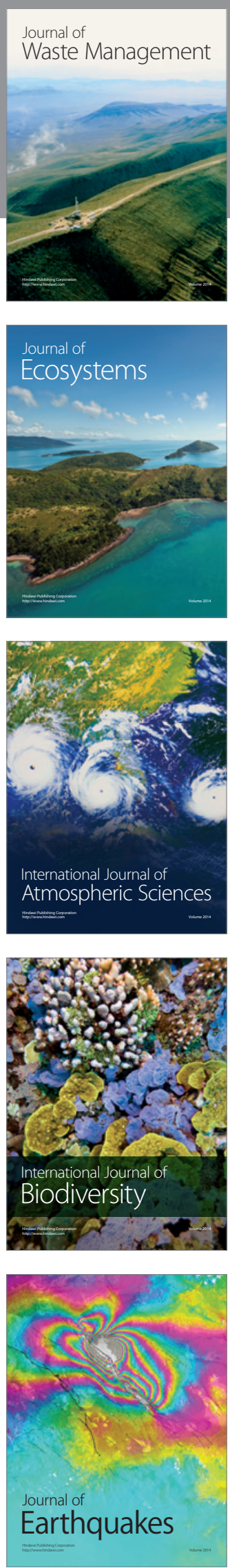
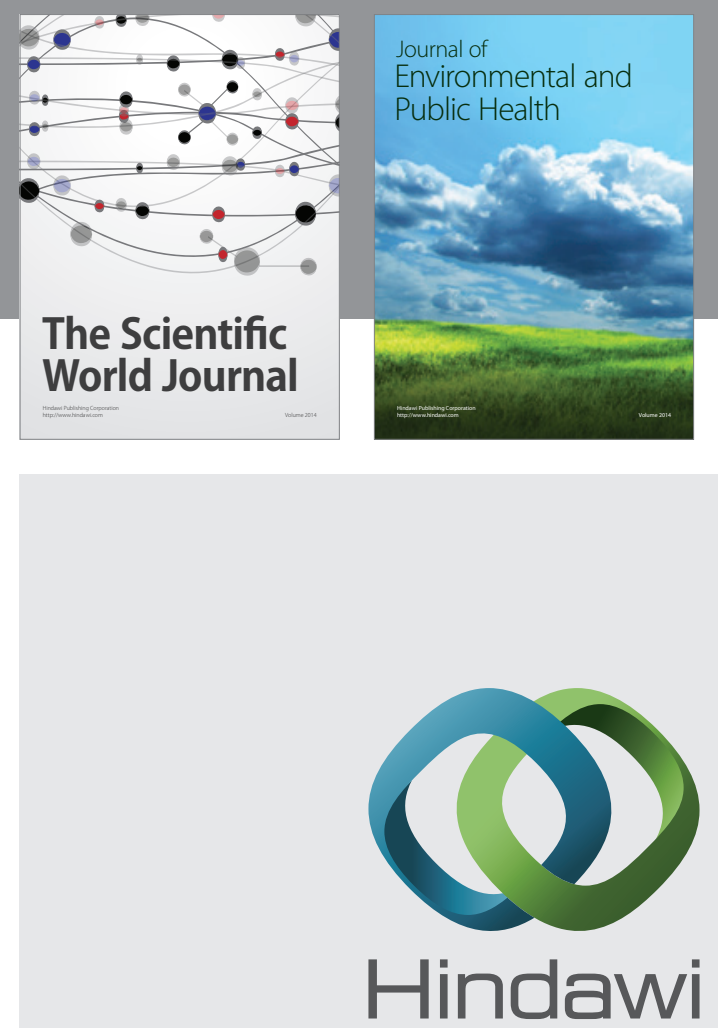

Submit your manuscripts at

http://www.hindawi.com
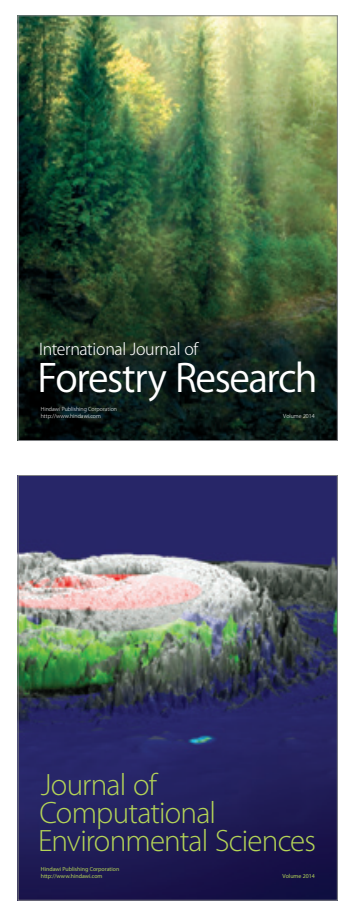
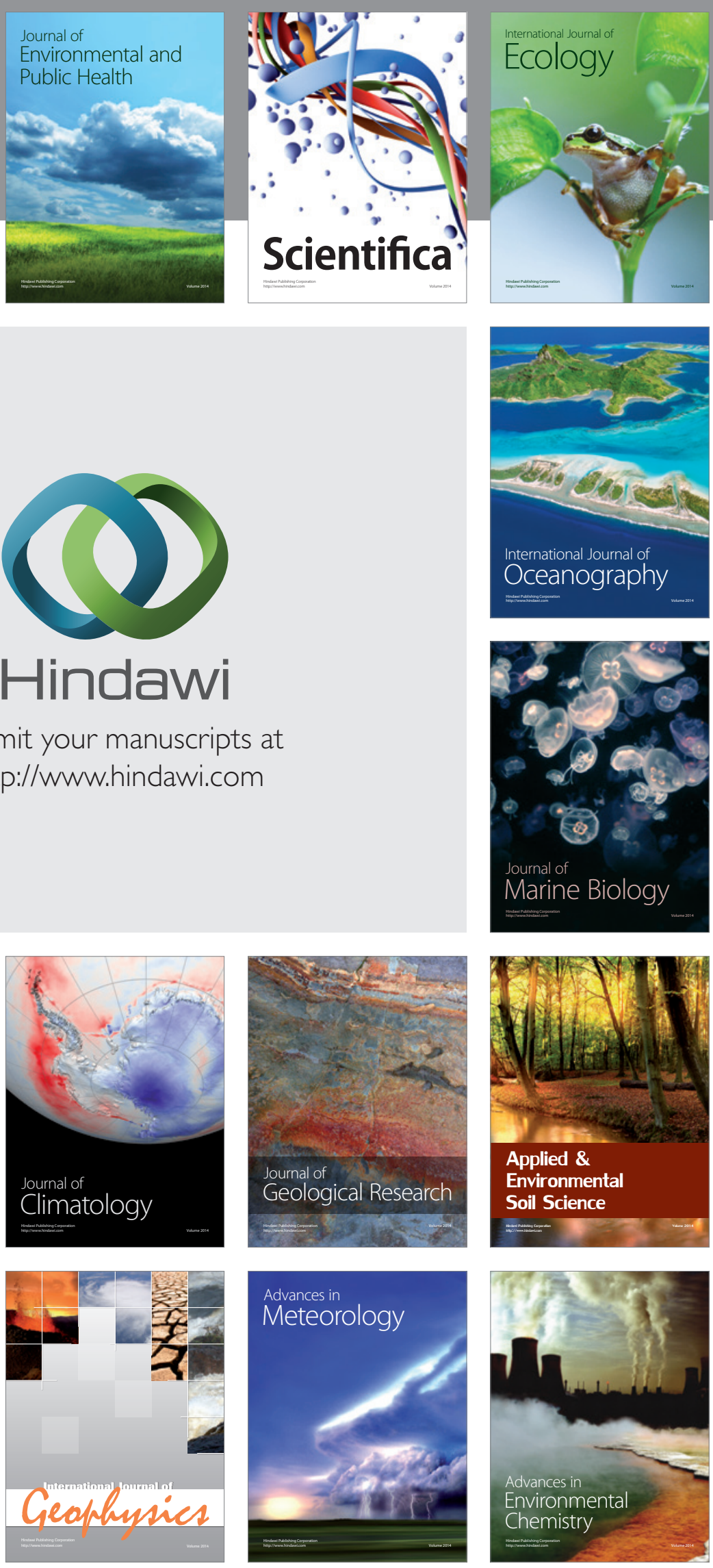